\title{
ECTOPIC HIDRADENOMA PAPILLIFERUM ASSOCIATED WITH PILOMATRICOMA - A CASE REPORT
}

L. Sushila Devi' ${ }^{1}$ Nisa Kaiho ${ }^{2}$, Dayananda Ingudam ${ }^{3}$

\section{HOW TO CITE THIS ARTICLE:}

L. Sushila Devi, Nisa Kaiho, Dayananda Ingudam. "Ectopic Hidradenoma Papilliferum associated with Pilomatricoma - A Case Report". Journal of Evolution of Medical and Dental Sciences 2014; Vol. 3, Issue 07, February 17; Page: 1615-1618, DOI: 10.14260/jemds/2014/2033

\begin{abstract}
Hidradenoma papilliferum is a rare, benign adnexal tumor considered to be of apocrine origin that occurs almost exclusively in females on the anogenital area. Ectopic or non- anogenital hidradenoma papilliferum is rare. But ectopic hidradenoma papilliferum associated with pilomatricoma has not been described in literature to our knowledge. We describe a case of hidradenoma papilliferum associated with pilomatricoma presenting with an intradermal nodule, $1 \mathrm{~cm}$ in diameter on the right side of the back of the neck with history of 15 years duration. This case is reported because of its rarity.
\end{abstract}

KEYWORDS: Hidradenoma papilliferum, pilomatricomas, adnexal tumor.

INTRODUCTION: Hidradenoma papilliferum is a benign, cystic papillary tumor considered to be of apocrine origin that occurs almost exclusively on the skin of the anogenital region in middle aged females. ${ }^{1}$ Even though it generally behaves in a benign fashion, rare malignant changes in the form of aggressive adenosquamous or squamous cell carcinoma can occur. Non-anogenital or ectopic hidradenoma papilliferum is rare and malignant change does not occur. ${ }^{2}$ Pilomatricomas (calcifying epithelioma of Malherbe) are benign appendage tumors related to hair cells matrix. ${ }^{3}$ They are usually solitary, asymptomatic, intradermal nodules with predilection for head and neck region. A 52 year old male with ectopic hidradenoma papilliferum in the neck associated with pilomatricoma is presented here.

CASE REPORT: A 52 year old male with an intradermal nodule of $1 \mathrm{~cm}$ diameter on the right side of the back of the neck reported for Fine needle aspiration cytology (FNAC) examination. The overlying skin exhibited a bluish discoloration. History of more than 15 years duration with gradual increase in size was given.

Aspiration smears showed a moderately cellular smear with a monomorphic population of benign looking epithelial cells in dispersed and loose clusters. A tentative diagnosis of benign adnexal lesion was made. Subsequent histopathological examination using hematoxylin and eosin (H\&E) stain showed a well circumscribed dermal nodule surrounded by a fibrous capsule with no connection with overlying epidermis. The nodule consisted of a cyst with large arborizing papillae having fibrovascular cores. The papillary folds were lined by a double layer of cells consisting of an inner layer of secretory (columnar) cells showing evidence of decapitation secretion and an outer layer of small cuboidal cells having basophilic nuclei, which are myoepithelial cells (Figure 1). A few heterotrophic apocrine glands were also seen adjacent to the tumor. A diagnosis of hidradenoma papilliferum was made. Histochemically, the luminal cells contained many large PAS positive diastase resistant granules in the secretory cells (Figure 2). Myoepithelial nature of the outer cell layer was confirmed by expression of smooth muscle actin and calponin (Figure 3). In the dermis, there were 


\section{CASE REPORT}

many cystic spaces lined by basaloid cells with shadow cells on the luminal surface and central eosinophilic areas of keratinization. The basaloid cells were round to oval with basophilic nuclei and scanty cytoplasm. Shadow cells were eosinophilic with a central unstained area as a shadow of the lost nucleus (Figure 4). Focal multinucleated foreign body type giant cells and calcification were also present representing reaction to keratin. The findings were consistent with pilomatricoma.

DISCUSSION: Hidradenoma papilliferum occurs as an intradermal nodule of $1 \mathrm{~cm}$ or less in diameter but may be as large as $1.5 \mathrm{~cm} .{ }^{4}$ It occurs almost exclusively on the skin of the anogenital region in middle aged females. Lesions occurring in anogenital region in males have also been reported. ${ }^{5}$ It usually occurs in third to fifth decades of life. ${ }^{6}$

Ectopic hidradenoma papilliferum is rare, of which $60 \%$ occur in head and neck region.4, 6-8 Other sites are extremities, chest and back. ${ }^{2,4,9}$ It has been postulated that these ectopic lesions arise in modified apocrine glands. ${ }^{2}$ It may be true in this case as a few ectopic apocrine glands were seen near the tumor. Association of hidradenoma papilliferum with nevus sebaceous of Jaddasohn has also been described in literature. But such association is not observed in this case. In contrast to anogenital lesions, nearly one-half of ectopic cases are seen in males. The median age for ectopic cases is 1 to 2 decades older than the average age range of onset in anogenital lesions. Eighty five percent of cases are $1.5 \mathrm{~cm}$ in diameter or smaller. Clinical features, treatment and prognosis for lesions occurring in anogenital and ectopic region are similar. ${ }^{4}$

Pilomatricoma is the most common hair follicle tumor. It occurs predominantly in children and young adults but are now being increasingly recognized in adults and the elderly. ${ }^{10,11}$ Slight male predilection has been reported in some studies. ${ }^{3}$ Though it generally occurs as a solitary lesion, multiple occurrences have been reported. ${ }^{12}$ The most common site was head and neck. ${ }^{3,13}$ Most of the cases were less than $2 \mathrm{~cm}$ in diameter. Malignant change is rare and tends to occur in middle-aged or elderly patients. ${ }^{13}$ Such changes are not observed in this case.

To conclude, ectopic hidradenoma papilliferum in the neck associated with pilomatricoma is a rare occurrence. These should be considered in the differential diagnosis of skin nodules on the head and neck, particularly in older patients for accurate diagnosis, appropriate treatment and to rule out malignancy.

\section{REFERENCES:}

1. Rosmaninho AD, de Almeida MT, Costa V, Sanches MM, Lopes C, Meirinhos MM. Ectopic hidradenoma papilliferum. Dermatol Res Pract 2010; 2010:709371.doi: 10. 1155/2010/709371.

2. Fernández-Aceñero MJ, Sánchez TA, Sánchez MC, Requena L. Ectopic hidradenoma papilliferum: a case report and literature review. Am J Dermatopathol 2003; 25:176-178.

3. Abdeldayem M, Mekhail P, Farag M, Shehata G, Al Sheikh M, Izzidien A et al. Patient profile and outcome of pilomatrixoma in district general hospital in United Kingdom. J Cutan Aesthet Surg 2013; 6(2):107-110.

4. Vang R, Cohen PR. Ectopic hidradenoma papilliferum: a case report and review of the literature. J Am Acad Dermatol 1999 Jul; 41(1):115-8.

5. Loane J, Kealy WF, Mulcahy G. Perianal hidradenoma papilliferum occurring in a male: a case report. Ir J Med Sci 1998; 167(1):26-7. 
6. Lee EJ, Shin MK, Haw CR, Lee MH. Two cases of hidradenoma papilliferum of the nose. Acta Dermato-Venereologica 2010; 90:323-3.

7. Minami S, Sadanobu N, Ito T, Natsuaki M, Yamanishi K. Non-anogenital (ectopic) hidradenoma papilliferum with sebaceous differentiation: a case report and review of reported cases. J Dermatol 2006 Apr; 33(4):256-9.

8. Lee HJ, Lee D, Jung SY, Hong SK, Seo JK, Sung HS. Hidradenoma papilliferum occurring on the nasal skin. Ann Dermatol 2011 Oct; 23(Suppl 2):S254-S7.

9. Tanaka M, Shimizu S. Hidradenoma papilliliferum occurring on the chest of a man. J Am Acad Dermatol 2003;48(2):S20-1.

10. Julian CG, Bowers PW. A clinical review of 209 pilomatricomas. J Am Acad Dermatol 1998;39:191-5.

11. Kaddu S, Soyer HP, Cerroni L, Salmhofer W, Hödl S. Clinical and histopathologic spectrum of pilomatricomas in adults. Int J Dermatol 1994; 33 (10):705-8.

12. Reddy SS, Gadre SA, Adegboyega P, Gadre AK. Multiple pilomatrixomas: case report and literature review. Ear nose throat J 2008;87(4):230-3.

13. Zaman S, Majeed S, Rehman F. Pilomatricoma - study on 27 cases and review of literature. Biomedica 2009;25(8):69-72.

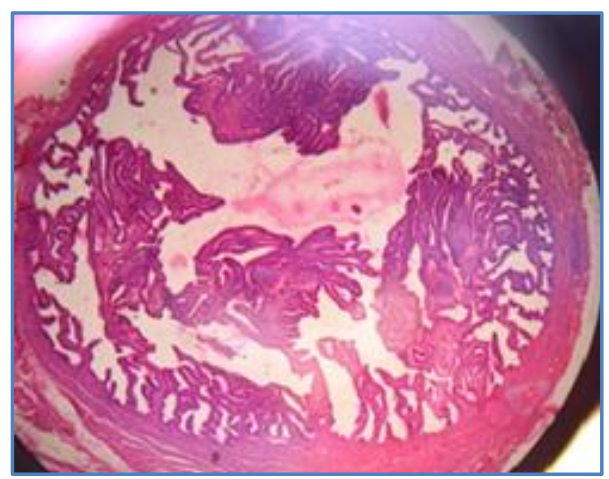

Fig. 1: Hidradenoma papilliferum (H\&E, X10)

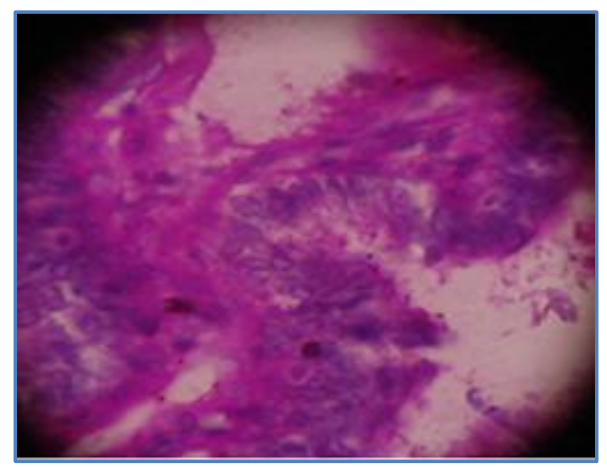

Fig. 2: Hidradenoma papilliferum (PAS, X100) 


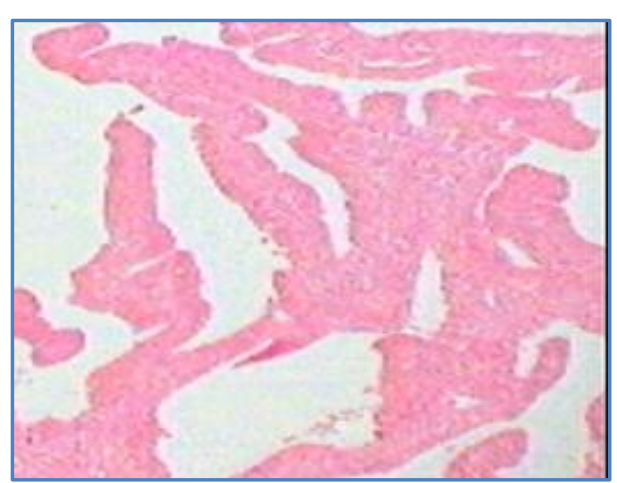

\section{Fig. 3: Hidradenoma papilliferum (Calponin, x40)}

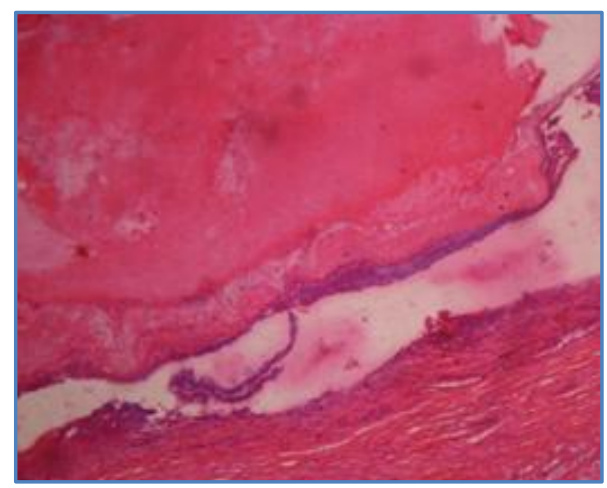

\section{Fig. 4: Pilomatricoma (H\&E, x40)}

\section{AUTHORS:}

1. L. Sushila Devi

2. Nisa Kaiho

3. Dayananda Ingudam

\section{PARTICULARS OF CONTRIBUTORS:}

1. Assistant Professor, Department of Pathology, Jawaharlal Nehru Institute of Medical Sciences (JNIMS), Imphal, Manipur.

2. Senior Resident, Department of Pathology, Jawaharlal Nehru Institute of Medical Sciences (JNIMS), Imphal, Manipur.

3. Senior Resident, Department of Pathology, Jawaharlal Nehru Institute of Medical Sciences (JNIMS), Imphal, Manipur.

\section{NAME ADDRESS EMAIL ID OF THE CORRESPONDING AUTHOR:}

Dr. Nisa Kaiho,

Department of Pathology,

Jawaharlal Nehru Institute of Medical Sciences (JNIMS),

Imphal, Manipur.

E-mail: nkaiho@rocketmail.com

Date of Submission: 17/01/2014.

Date of Peer Review: 18/01/2014.

Date of Acceptance: 03/02/2014.

Date of Publishing: 11/02/2014. 